\title{
max \\ New Models to Reduce the Health Risks of Informal WEEE Recyclers in MTN Phone Village, Rumukurushi, Port Harcourt, Nigeria
}

\author{
Ogechukwu Okwu ${ }^{1, *}$, Andrew Hursthouse ${ }^{1}$ D, Evi Viza ${ }^{1}$ and Linus Idoko ${ }^{2}$ \\ 1 School of Computing, Engineering \& Physical Sciences, University of the West of Scotland, \\ Paisley PA1 2BE, UK; andrew.hursthouse@uws.ac.uk (A.H.); evi.viza@uws.ac.uk (E.V.) \\ 2 Department of Electronic \& Computer Engineering, Veritas University, Bwari, Abuja 900001, Nigeria; \\ idokol@veritas.edu.ng \\ * Correspondence: ogechukwu.okwu@uws.ac.uk
}

check for updates

Citation: Okwu, O.; Hursthouse, A.; Viza, E.; Idoko, L. New Models to Reduce the Health Risks of Informal WEEE Recyclers in MTN Phone

Village, Rumukurushi, Port Harcourt, Nigeria. Toxics 2022, 10, 84. https:// doi.org/10.3390/toxics10020084

Academic Editor: Elena Semenzin

Received: 13 January 2022

Accepted: 9 February 2022

Published: 12 February 2022

Publisher's Note: MDPI stays neutral with regard to jurisdictional claims in published maps and institutional affiliations.

Copyright: (C) 2022 by the authors. Licensee MDPI, Basel, Switzerland. This article is an open access article distributed under the terms and conditions of the Creative Commons Attribution (CC BY) license (https:// creativecommons.org/licenses/by/ $4.0 /)$.

\begin{abstract}
Waste electrical and electronic equipment (WEEE) management in Port Harcourt, an oilproducing city in Nigeria, has become an environmental challenge for the location. WEEE recycling is predominantly managed by informal recyclers, who lack the skills to perform risk-free recycling, hence raising health risks to individuals in associated communities and degrading the environment. Formal recycling, which embraces the best practices for effective WEEE management, is faced with several limitations, such as a lack of detailed guidelines on waste recycling, reuse, and final disposal techniques, with no opportunities for landfilling. A qualitative approach was adopted for this study. Data were gathered via questionnaires and analysed graphically. A background literature review of the assessment of informal recycling methods and associated challenges was performed. Hence, a new concept for the local management of WEEE processing was introduced. This concept limits the role of informal recyclers to WEEE collection. In this case, informal recyclers are paid for WEEE collection; they no longer engage in further WEEE processing. The results show that $48 \%$ and $40 \%$ agree to partner and collaborate with government agencies, respectively. Conversely, $52 \%$ and $40 \%$ agree and strongly agree, respectively, to limit their activities to WEEE collection only if the government is willing to pay for the services.
\end{abstract}

Keywords: informal recycling; Port Harcourt; WEEE management; hazard; risk assessment

\section{Introduction}

Port Harcourt, an oil-producing city in Nigeria, experiences a massive number of individuals arriving in search of financial benefits from the oil and gas industries. Because of this ever-rising number of inhabitants there is an increase in the consumption of materials as well as the generation of waste electronic and electrical equipment (WEEE) and other environmental contaminants. The quantity of WEEE produced has been steadily increasing [1]. Furthermore, according to the same study this is largely a result of the increasing need for information and communications technology as well as enhanced technology in some parts of the world, resulting in the dumping of "old and discarded" electronic and electrical equipment to countries such as Nigeria, where such items are still useful. These items are usually obsolete or close to obsolescence before they are transported to poor nations, which tends to increase the quantity of generated WEEE. According to [2], WEEE, which is among the biggest and constantly increasing streams of global waste, has become an issue of serious concern due to its associated challenges. The problem created by WEEE appears to be twofold. First and foremost, it is among the most rapidly increasing waste streams globally, presenting a potential threat to humans, animals, and the environment as a result of its mismanagement. Secondly, as a result of its composition, which is complex, WEEE is also one of the most difficult waste streams to manage effectively [3]. In Port 
Harcourt, a city in the south-south geopolitical zone of Nigeria, the WEEE collectors do not practice formal recycling methods. The system in practice is the informal recycling method, carried out primarily at the dumpsite, where they engage in the sorting of WEEE as well as further recycling [4]. This begs the following question: how can we tackle the challenges associated with informal recycling?

Ohajinwa et al. [5] put forward the notion that informal recyclers engage in several activities, which include the recycling of WEEE. Their services are usually provided at a low cost, but the working procedure used is not safe; hence, their health is at risk from exposure to substances within the materials and from the operations used in recycling, such as burning to remove plastics. In a related study [4], WEEE and other waste are usually gathered unsorted at locations in Port Harcourt, such as Igwuruta, Elelenwo, and Abuloma. WEEE serves as a source of raw materials, but during the informal recycling process the estimated recovery of useful metals is only $25 \%[6,7]$.

In a study on WEEE generation by Mihai et al. [8] this growing waste stream and its inappropriate handling generate serious pollution- and health-related challenges. This can result from the dismantling of WEEE being carried out under "poor conditions". The dumping of WEEE in Africa has been significant for a long period, and its recycling is usually carried out by poorly educated individuals, under temporary conditions, with no infrastructure, which leads to exposure to harmful substances. Due to a lack of organised collection centres in Nigeria WEEE is dumped together with waste from hospitals and other sources in the community, which causes the situation to be more complex. In some communities WEEE is dumped in bodies of water and on open fields, resulting in direct environmental pollution. Items considered to be of no use economically are usually burnt regularly to reduce their quantity or directly deposited on open fields or in water bodies. The indiscriminate discarding of WEEE has resulted in an increase in polybrominated diphenyl ether and polychlorinated biphenyl concentration in individuals. Fluorinated biphenyls and analogues are also toxic pollutants emitted due to the indiscriminate dumping of WEEE [9-14].

Electronic appliances such as televisions and computer monitors contain potentially harmful elements and compounds, which are evident during disposal or recycling. The majority of those who make use of them are not aware of the associated risks of using them frequently [15]. The landfills, as well as unauthorised dumpsites, appear to be the terminal point of the majority of the gathered WEEE [16]. Harmful gases are usually released into the environment during the burning of WEEE [12,17]. The disposal and recycling of cathode ray tubes (CRTs) have the potential to expose life to health risks due to the presence of lead in CRT funnel glass (at levels up to 22\%). In addition to lead, CRTs consist of fluorescent powders, barium, and cadmium, all of which are toxic. The harmful elements contained in CRTs are easily absorbed in the soil over time and are consequently passed to humans and animals [18-21]. The presence of devices that contain mercury causes soil pollution and contributes to increased health risks. Mercury is more poisonous than lead and cadmium, and it causes loss of hearing and vision as well as developmental delays [22-24]. The tissue and surface of locally grown fresh vegetables can easily become contaminated when exposed to residues from waste processing directly deposited on fields and in water. Skin contact and drinking water have also been recognised as significant routes of exposure to toxic substances [25-27].

Unprofessional WEEE burning and dismantling methods contribute significantly to the pollution of air. This can result in secondary exposure, as some of the pollutants are able to travel over a long distance to other locations from the recycling sites [28]. The soil, as well as the crops grown in the WEEE dumpsites, are usually exposed to a high concentration of metals, such as lead, zinc, copper, etc. The accumulation and uptake of them by plants constitute the major entry channel for metals, which are toxic in animal and human food. Examples of such toxic metals are metalloids such as lead, mercury, cadmium, selenium, and arsenic. Crops that grow in the metal-polluted locations usually show a reduction in growth, reduced biomass production, accumulation of metal, and 
alteration of metabolism. It is common practice for locals to grow crops around and within WEEE dumpsite areas, as they believe the land is fertile and that crops will grow well. Research has demonstrated that many locations contain high levels of potentially toxic elements [29-32]. The pollutants in WEEE migrate towards biological and environmental receptors via several pathways [33]; the most relevant for informal recycling activities in Nigeria are summarised in Figure 1.

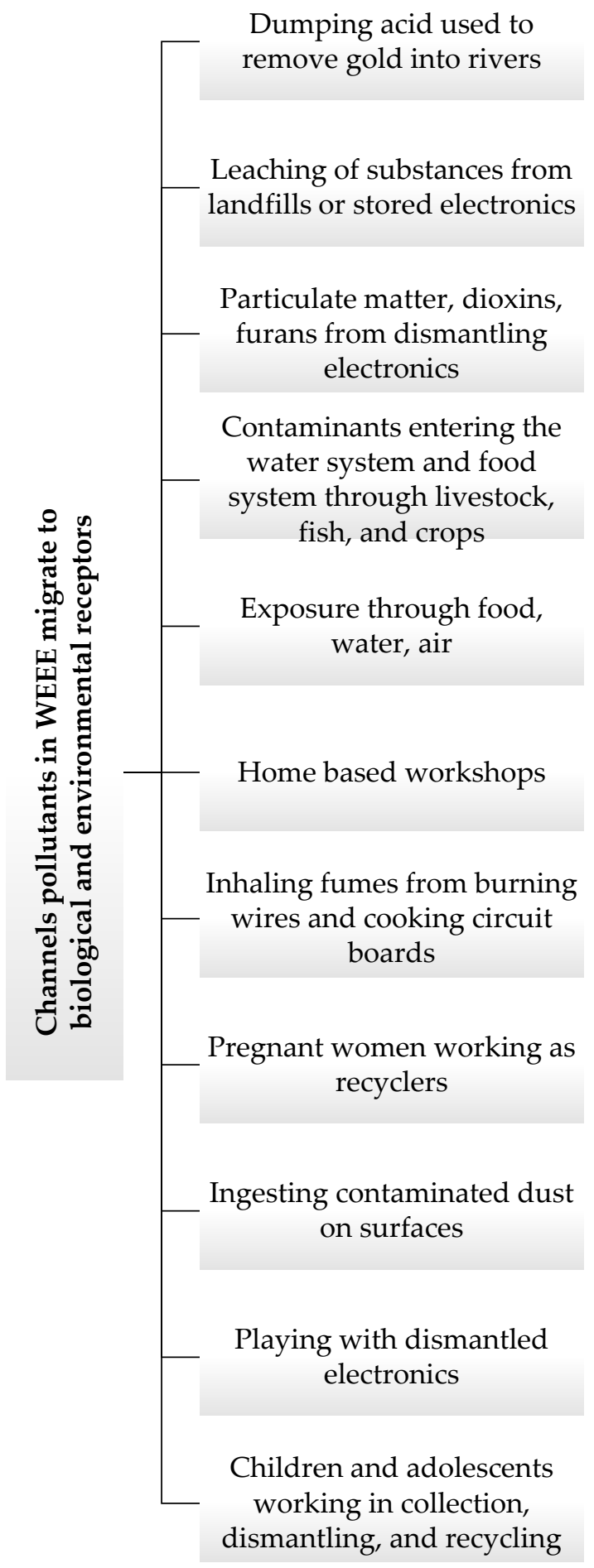

Figure 1. Channels pollutants in WEEE migrate to biological and environmental receptors.

In recent research conducted by George et al. [34] the increasing quantity of WEEE is shown to be associated with several factors, which include technological improvement, the 
availability of assorted electronic and electrical devices for sale, the reduction in prices of electronic and electrical devices, and the growing population, fuelling an extremely "high demand" for them. WEEE is a potential source of rare metals and useful plastics, helpful in reducing the pressure on mineral resources, the exploitation of natural resources, as well as the environmental and cost implications of mining. Several methods are adopted to extract metals. For example, studies have shown that the copper present in printed circuit boards (PCBs) can be extracted with the use of a mixture of aqueous acid and supercritical $\mathrm{CO}_{2}$. Studies have also shown that rare earth elements can be recovered via electrochemical recovery. In a recent study, important metals, such as copper, silver, and gold, were recovered from the printed circuit boards of computers that were no longer in use via physical separation, after which a leaching technique was applied. In addition, copper can be directly separated and recovered from waste PCBs via slurry electrolysis carried out with an acidic system. Product designs that are environmentally friendly have been encouraged in the European Union via legislation to support the recovery of valuable materials from WEEE [35-41].

In [42] "the recovery and treatment of WEEE" serve as an alternative source of important elements, for example, copper, gold, etc. However, the indiscriminate disposal of WEEE and the challenges that come with the inappropriate disassembling and management of WEEE, observed in many developing countries, put pressure on the environment and human health [43].

An assessment by Khan et al. [44] indicates that most of the WEEE that is globally generated, amounting to at least 40 million tonnes per year, finds its way to developing countries. Nigeria now appears as one of the locations receiving WEEE from Asia, the US, and Europe [45]. A study by Ferronato and Torretta [43] put forward the notion that developed countries have seen the export of WEEE to Asia and Africa as a preferred option compared to developing their own national recycling infrastructure, encouraging innovative design that limits toxic material use, or switching to cleaner sustainable technologies. In [46] it was observed that the amount of WEEE generated worldwide amounted to approximately "50 million metric tonnes" in 2018. WEEE production is the direct consequence of the manufacturing and use of electronic devices driven by the multipurpose nature of information and communications technologies (ICTs). This increased consumption and comparatively short life of electronics result in a build-up of WEEE, which poses problems at all levels. The hazardous materials in WEEE pose problems for the government in terms of their management [47] and effect on the environment [48]. The estimated quantity of WEEE produced worldwide in 2018 increased to 49.8 metric tons [46]. The major generators of WEEE as of 2014 identified in the same study by Adeola [46], and that of Tiseo [49], are shown in Table 1 and Figure 2, respectively. The statistics show that the United States tops the list in WEEE generated in 2014, while China tops the list in WEEE generated in 2016.

The generation of WEEE and its collection in different continents is identified in Baldé et al. [50] and is summarised in Table 2.

Baldé et al. [50] reported that, in the year 2016, of the bulk of WEEE gathered in Asia, which amounts to 18.2 million metric tons (Mt) (i.e., $4.2 \mathrm{~kg} /$ inhabitant), only about $2.7 \mathrm{Mt}$ was recorded for collection and will be recycled. Oceania produced the highest amount, $17.3 \mathrm{~kg} /$ inhabitant, and had only a $6 \%$ rate of collection and recycling; however, it appears to produce the smallest amount of WEEE in 2016: 0.7 Mt. The statistics for Europe, Asia, the Americas, and Africa are also shown in Table 2. These statistics imply that a large proportion of the WEEE that is collected and recycled is not documented.

We focus on the need to eliminate or reduce the role of recyclers in the informal sector, in particular, to reduce health risks from the management of WEEE in Rumukurushi, in Port Harcourt, Rivers State, Nigeria. This is applicable to similar situations in other cities.

\subsection{A Review of the Literature on WEEE Management}

Several studies have focused on improving the informal management of WEEE. Ogbuanya and Afeez [51] (p. 90) propose that the WEEE approaches applied in the workshops 
of "electrical/electronic technicians" can be advanced. Data collection was performed using questionnaires administered to 54 "public health" senior staff as well as 87 engineering lecturers. The data analysis was achieved using "percentage, mean, and standard deviation white $t$-test and ANOVA". The study findings reveal that providing a "recycling site" as well as introducing and applying regulatory policies are the major approaches required for a more effective management of WEEE. However, the study did not directly address the challenges associated with informal recycling but only attempted to identify indicators that may be of help. A study on effective methods that can help to proffer solutions for WEEE management would be valuable.

Table 1. Top ten global generators of WEEE, in total mass and per capita, and the presence of national regulations, 2014.

\begin{tabular}{ccccc}
\hline SN & Country & Mass (kilo tons) & National Regulation & Per Capita (tons) \\
\hline 1 & US & 7072 & No & 22.1 \\
\hline 2 & China & 6033 & Yes & 4.4 \\
\hline 3 & Japan & 2200 & Yes & 17.3 \\
\hline 4 & Germany & 1769 & Yes & 21.6 \\
\hline 5 & India & 1641 & No & 1.3 \\
\hline 6 & UK & 1511 & Yes & 23.5 \\
\hline 7 & France & 1419 & Yes & 22.1 \\
\hline 8 & Brazil & 1412 & No & 7.0 \\
\hline 9 & Russia & 1231 & No & 8.7 \\
\hline 10 & Italy & 1077 & Yes & 17.6 \\
\hline
\end{tabular}

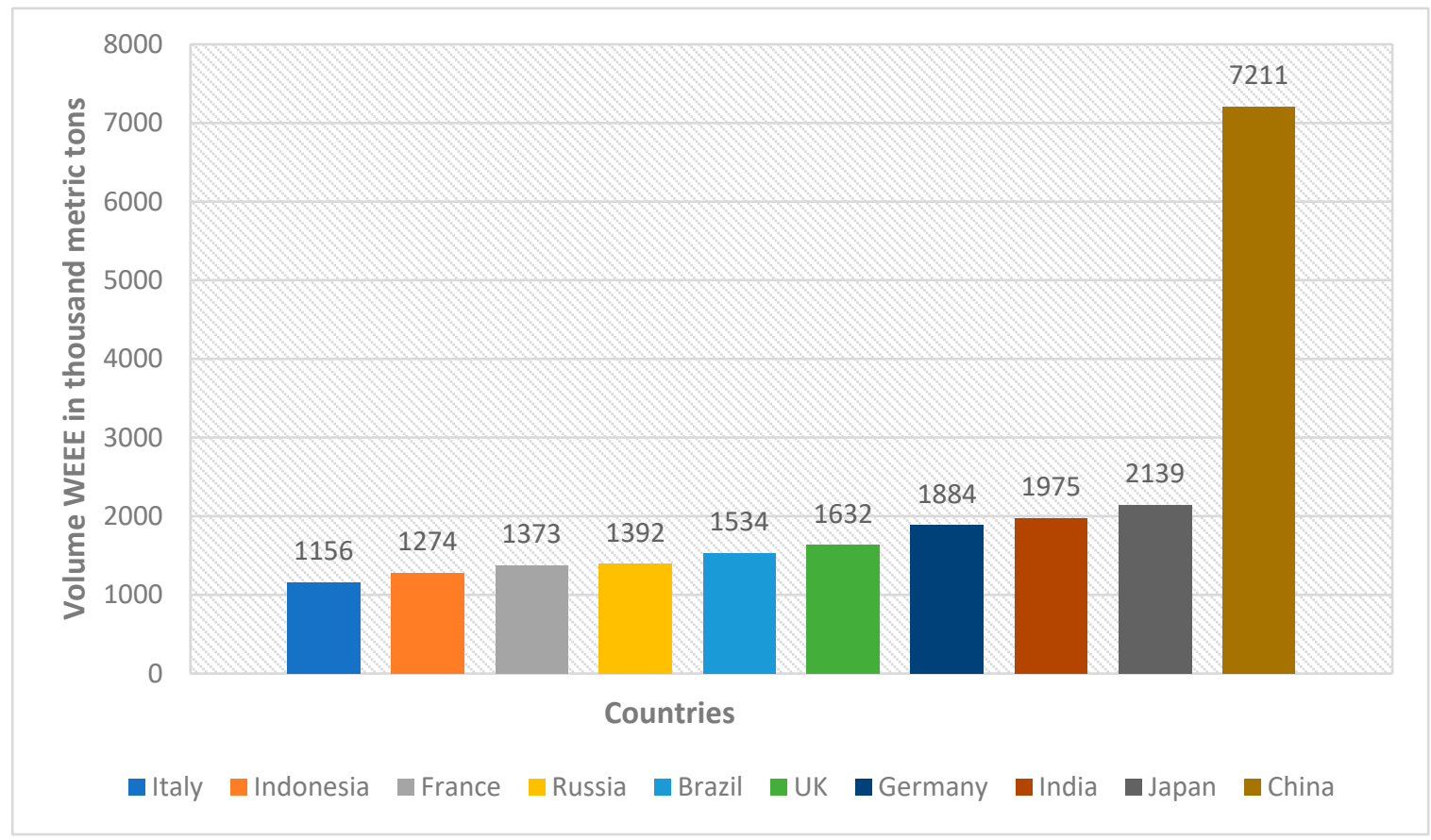

Figure 2. Global generation of WEEE in 2016. 
Table 2. The generators of WEEE and its collection per continent.

\begin{tabular}{|c|c|c|c|c|c|}
\hline Indicators & Oceania & Europe & Asia & America & Africa \\
\hline Countries within the region & 13 & 40 & 49 & 35 & 53 \\
\hline Population within the region (millions) & 39 & 738 & 4364 & 977 & 1174 \\
\hline Water gauge, WG (kg/inh) & 17.3 & 16.6 & 4.2 & 11.6 & 1.9 \\
\hline Indication WG (Mt) & 0.7 & 12.3 & 18.2 & 11.3 & 2.2 \\
\hline WEEE documented to be collected and recycled (Mt) & 0.04 & 4.3 & 2.7 & 1.9 & 0.004 \\
\hline Rate of WEEE collection within the region & $6 \%$ & $35 \%$ & $15 \%$ & $17 \%$ & $0 \%$ \\
\hline
\end{tabular}

Arya et al. [52] investigate the degree of understanding of informal recyclers and users (individuals, organisations, and companies) with regard to the hazards created by WEEE. The study collected data via questionnaires administered to three different WEEE stakeholder groups, namely organisations, individuals, and those who use WEEE recycling services. The composition of those who responded to the questionnaires was 10 persons engaged in WEEE recycling, 25 users of electrical and electronic appliances, and 35 organisations considered as users. The study outcomes revealed that the individuals and organisational users lack an understanding of the problems associated with WEEE management. This includes legislation for WEEE management and proper channels for the collection of WEEE. Recyclers in the informal sector were not aware of the risks associated with WEEE and subsequently engaged in unsafe disposal methods. The study did not address the challenges associated with informal recycling, because it primarily focused on the degree of understanding of the informal recyclers and users. The study identified health and safety training as an avenue to increase awareness.

George et al. [34] studied WEEE management with households as their main focus, using an assessment of the electrical and electronic device composition in the apartments of the people in the area of study as well as the way in which WEEE was managed. Data collection for the study was achieved using questionnaires. The study outcomes revealed that the electronic and electrical appliances that appear the most in the area are phones. Furthermore, the study revealed that the selected area adopted an unsustainable system of managing WEEE. Study participants did not recycle WEEE, but simply kept them inside their homes or deposited them directly into the general waste stream. The study did not address the challenges associated with informal recycling because no evaluation was conducted on the activities of informal recyclers; instead, recommendations were offered. Introducing an approach with the potential to provide an effective recycling solution may be helpful in the informal sector.

Ndunda and Ambole [53] (p. 73) tackled the problems introduced by the informal method of WEEE recycling via the creation of "a product-service system" for its management. Supporters of a move, from product provision to "provision of systems of products and services" were developed alongside stakeholders' support, in order for WEEE to be managed efficiently. Dematerialization technique was applied in the study by making use of the effort of stakeholders' collaboration, this hinders the informal recyclers or consumers from having possession of equipment after EOL. The outcome indicates that the collaborative efforts of those involved determine the success of the technique. How has the study addressed the challenges associated with informal recycling? The study was unable to address the problem because dematerialisation can only be attained through structural and technological changes in the area, which have yet to be implemented. Adopting an approach applicable to developing nations would be more useful.

In Aidonis et al. [54] a methodology was created to recognise an optimal management scheme for WEEE in order to find another means of integrating WEEE. The study made use of a binary linear programming model to improve the effectiveness of nine options to manage WEEE. Consideration was given to 12 performance criteria, including environmental, financial, social, and technical considerations. The study outcome revealed 
that the best approaches were exporting WEEE residue and mechanically recycling WEEE. The outcome did not address the issues associated with informal recycling because the technique proposed does not have the potential to tackle the negative repercussions of informal recycling. A technique that has the potential to minimise informal recycling may be more useful.

In Mihai et al. [8] statistical information on waste and "thematic cartography" was used to disclose how WEEE moves from one geographical location to another. The approaches utilised to manage WEEE in numerous locations were examined, for instance, in Europe, North America, South America, Oceania, Africa, etc. The findings indicate that inadequate infrastructure leads to the poor management of WEEE in Africa. The findings did not address the issues associated with informal recycling, as the study focused on elements of the improper management of WEEE. Identifying a useful method that can tackle the challenges facing recycling in the informal sector may be helpful.

\subsection{Research Gap}

It is therefore clear that no major improvements have been achieved to reduce the activities of informal recyclers in Nigeria and other developing countries where WEEE management is predominantly managed by the informal sector. Our study addresses this issue by assessing models for the continued participation of recyclers in the informal sector in the collection of WEEE.

\subsection{WEEE Status in Nigeria}

Goel [55] (p. 8) reports that, as a result of the lack of proper waste management infrastructure and systems in Nigeria, the dumping of WEEE is usually carried out "alongside other municipal waste"; hence, the level of health and environmental risk awareness is "generally low". The same study explains that the lack of appropriate mechanisms in Nigeria for WEEE "disposal" contributes immensely to the poor knowledge of WEEE disposal and the associated health risks. The inadequate rules and regulations, as well as the poor implementation of laws on sanitation, have created an enabling environment for informal recycling in some parts of Nigeria [56]. The task performed by informal WEEE recyclers is significant and includes the collection of WEEE from streets for recovery, recycling, sorting, and disposal [57]. The job of the informal recycler entails material isolation, dismantling via the use of manual techniques, circuit board heating, the recovery of metal using poisonous acid, and disposal at an open dump [5].

Informal recyclers, also referred to as "scavengers", usually lack formal skills and are unregistered [58]. A total of 277,000 tonnes of WEEE was generated in Nigeria in 2016. This puts Nigeria in the third position in the hierarchy of WEEE generators on the African continent, with the amount of WEEE expected to increase. No non-governmental or institutional organisation collects or updates data on WEEE, which would serve as a source of valuable information to support policymaking or government action. In addition, a large quantity of WEEE enters the country "from abroad" [50,55]. Some locations in Nigeria, such as Lagos, stockpile WEEE, awaiting the provision of a means to recycle it [45]. The challenges associated with the management of WEEE in Nigeria and other developing countries are further amplified due to the absence of comprehensive and reliable data $[59,60]$.

The problems associated with WEEE management in Africa are well-known, but it still lacks the appropriate infrastructure, evidenced by the absence of appropriate regulatory protocols and enforcement [61]. In the informal sector WEEE is recycled improperly, and the process exposes the community as well as the environment to risk. In general, workers engaged in the informal sector are not aware of the risk associated with potentially toxic and hazardous substances contained in WEEE. Hence, their exposure to these substances can result in severe health challenges. The processing and discharge of toxic products from WEEE are typical of the informal sector. Recycling in the informal sector is carried out without the use of technology and proper protection; thus, individuals incur great risk 
when processing WEEE [62-64]. Developing countries, e.g., Nigeria, lack the infrastructure required for effective WEEE management $[10,65]$.

Adequate awareness and sound understanding of WEEE, which are lacking in recyclers in the informal sector, are necessary to reduce risks to health as well as ineffective disposal, recycling, and reuse. Informal recyclers are usually not registered with the appropriate authorities in their location, and their services are thus illegal [66-68].

There is a challenge with the adoption of the extended producer responsibility in several parts of Africa, for example, Nigeria [10,69]. WEEE constitutes a great deal of waste material, both hazardous and non-hazardous. Informal WEEE recycling exposes the recyclers and the neighbouring environment to polybrominated biphenyls, chromium, mercury, cadmium, and lead. This can affect the liver, kidneys, nervous system, and brain. WEEE, which is usually present in municipal solid waste, can give rise to severe health challenges and environmental pollution from the facilities used for incineration and pulverising/disassembling, as well as from sanitary landfills and unauthorised dumping sites [69-72].

Some of the elements in WEEE that are capable of causing risks to human health and the environment are identified in [73] and shown in Table 3.

Table 3. Typical WEEE components and their adverse health effects.

\begin{tabular}{|c|c|c|}
\hline E-Waste Component & Adverse Health Effects & $\begin{array}{l}\text { Electronic \& Electrical } \\
\text { Appliances with These } \\
\text { Components }\end{array}$ \\
\hline Sulphur & $\begin{array}{l}\text { Throat \& eye irritation, Liver, } \\
\text { Kidney and heart damage }\end{array}$ & Lead-acid batteries \\
\hline Arsenic & $\begin{array}{l}\text { It has negative effect on Liver, } \\
\text { skin, respiratory and nervous } \\
\text { system }\end{array}$ & Phones, Microchips \\
\hline Carcinogenic powder & Skin irritation, cancer & Ink Cartridges/toner \\
\hline $\begin{array}{l}\text { Brominated Flame } \\
\text { retardants }\end{array}$ & $\begin{array}{l}\text { Brain damage, thyroid and liver } \\
\text { problems }\end{array}$ & Most electronic plastics \\
\hline Cadmium & $\begin{array}{c}\text { Neuromotor deficit in children, } \\
\text { severe damage to kidney and } \\
\text { lungs }\end{array}$ & $\begin{array}{l}\text { Phone battery, } \\
\text { Nickel-Cadmium } \\
\text { rechargeable lamps }\end{array}$ \\
\hline Mercury & $\begin{array}{l}\text { Kidney damage, dermatitis, } \\
\text { slower growth, reduce fertility, } \\
\text { muscle weakness, memory loss }\end{array}$ & $\begin{array}{c}\text { Phones, flat screen } \\
\text { TVs/monitors, mechanical } \\
\text { door bells, Fluorescent tubes }\end{array}$ \\
\hline Lead & $\begin{array}{l}\text { Lower IQ, hyperactivity, attention } \\
\text { deficits, behavioural disturbances, } \\
\text { nervous system damage. }\end{array}$ & $\begin{array}{l}\text { Circuit boards, lead acid } \\
\text { batteries, CRT monitors, } \\
\text { some PVCs }\end{array}$ \\
\hline
\end{tabular}

\subsection{Recycling Methods in Nigeria}

The two types of recycling methods are those practiced by informal recyclers, also known as scavengers, and those practiced by formal recyclers. Both sectors have a target, which is the management of WEEE in a manner that is profitable and sufficient to ensure that waste is not diverted into the major public waste stream and landfills [74]. Operations common to both informal and formal recyclers, as specified in [75], are the collection, dismantling via the use of manual techniques, recycling, reconditioning, and extraction of cables, metals, plastics, and "printed circuit boards" present in WEEE. In most of the countries referred to as developing, the activities of the informal recycler commence from the moment WEEE is collected and end at the final stage, depending on the available options [76]. The collection as well as the recycling of WEEE in Nigeria is primarily carried out by extremely poor rural Nigerians [58]. The informal recyclers carry out their recycling duties in workshops, which are usually small or in the open air [77]. 
Countries that are industrialised, such as the US, UK, Sweden, Finland, and Germany, which usually have and maintain "stricter environmental laws and regulations", practice formal WEEE recycling [74]. Meanwhile, informal WEEE recycling is carried out in countries such as Nigeria, India, Pakistan, Ghana, and China, where environmental laws and regulations are not strictly enforced. Some studies have suggested that informal recyclers make use of common "extraction tools" and systems such as mallets, hammers, screwdrivers, chemical leaching, and open burning, in contrast to formal recyclers who carry out their activities under controlled conditions and with standard equipment. Some of the differences between the informal method of recycling WEEE in Port Harcourt, Nigeria, and the formal methods practiced in other countries, for example, Mexico, are shown in Table 4 [75].

Table 4. Differences between informal recycling in Port Harcourt, Nigeria, and formal recycling in other countries, e.g., Mexico.

\begin{tabular}{|c|c|}
\hline Informal Recycling & Formal Recycling \\
\hline $\begin{array}{l}\text { Pickers either collect WEEE or they are } \\
\text { provided it by consumers }\end{array}$ & $\begin{array}{c}\text { WEEE is gathered via a collection service, } \\
\text { logistic service, collection campaign, or at a } \\
\text { clean point }\end{array}$ \\
\hline $\begin{array}{l}\text { Components are manually separated or } \\
\text { dismantled }\end{array}$ & $\begin{array}{c}\text { Components are mechanically separated or } \\
\text { dismantled }\end{array}$ \\
\hline $\begin{array}{l}\text { No recycling facilities, only primitive recycling } \\
\text { procedures exist }\end{array}$ & Recycling facilities exist \\
\hline No delivery to qualified waste managers & $\begin{array}{l}\text { Delivery to qualified waste managers takes } \\
\text { place }\end{array}$ \\
\hline No pretreatment & Pretreatment takes place \\
\hline
\end{tabular}

The informal waste management system is the dominant method in Nigeria; this is because formal waste management is faced with several challenges, as specified in [57], including:

a. Endless "political interference".

b. An absence of the required facilities and insufficient funds.

c. Unconcerned behaviour among staff members.

d. Unwillingness of those who generate waste to pay service providers.

e. The presence of "sophisticated equipment" without sufficient skills to operate such equipment.

f. Corruption and mismanagement of funds.

g. "Civil society" is usually not involved in the decision-making arrangements.

It is evident that the collection, handling, and refurbishing of WEEE is carried out by informal recyclers, who are largely illiterate, untrained, and without experience [78]. They are usually "undocumented business" persons, usually lack training and skills, and roam the streets and waste dumps with their handcarts to collect, or in rare cases, buy abandoned WEEE and other metal scraps, which contain important elements such as iron, brass, copper, aluminium, etc. Ohajinwa [79] explains that the recycling of most of the WEEE that is generated is carried out in an informal/unsafe way, such that toxic elements are released into the environment. Mihai et al. [8] report that informal WEEE recycling practices appear to dominate the Nigerian WEEE market. These informal recycling activities often happen in backyards or small workshops in Nigerian cities (Port Harcourt), where primary methods of manual disassembly and open burning are practiced. Primitive techniques such as manual dismantling, the melting of metals, acid dipping, and open burning are often utilised to recover valuable materials from WEEE. The informal recycler does not adopt optimised methodologies for material recovery; for example, metals are usually recovered via heating WEEE on a hot plate or over an open flame. In some instances WEEE is shredded mechanically to help recover valuable metals [80-83]. 
Metals can be recovered from depleted lithium-ion batteries using environmentally friendly techniques [84]. Nonferrous metals can be recovered from PCBs [85]. Plastic waste such as brominated resin can be recovered from WEEE using infrared heating [86]. WEEE is recycled by removing components or valuable materials, including integrated circuits (ICs), plastics, condensers, cathode ray tubes (CRTs), printed wiring boards (PWBs), and metals, which can be reprocessed directly as reusable components for raw materials [87]. The commonly practiced process of extracting these materials is through an open burning system, which is injurious to human health and the environment [82]. The actors in the informal sectors are cart pushers, scavengers (those who sort and recover materials that can be reused or recycled), resource merchants, and recyclers [57]. Despite the problems associated with the informal WEEE management system, it serves as a source of employment and a means of livelihood for many individuals [88].

The importance of recycling is not based on the proper treatment of WEEE but on the maximum recovery of valuables in discarded WEEE from dumpsites. The crude methods employed by informal recyclers cannot adequately remove the potentially toxic elements (PTEs) in WEEE [89]. Thus, funding by all stakeholders for the upgrading of recycling infrastructure and proper integration of the recycling and waste sectors in Nigeria is a necessity. However, studies have revealed that informal recycling methods and activities, such as dismantling, open burning of plastics and wire, and indiscriminate disposal, lead to a significant level of potentially toxic elements and persistent organic pollutant emissions in air, soil, and water. The existing pathways for soil pollution and the impact on humans are described in the following sections, detailing the methods and activities of WEEE management in the informal sector $[43,90]$.

Studies reveal that informal recycling activities, such as the open burning of wires and plastics, dismantling, and unregulated disposal, result in the release of significant levels of heavy metals as well as persistent organic pollutants into the soil, air, and underground as well as surface water [89,91]. However, a study carried out by Ezeudu and Ezeudu [91] shows that Nigeria does not have the capacity for formal recycling methods, in part due to the lack of modern recycling facilities in the country. Conversely, Omokaro [74] (p. 18) explains that the effort made to commence formal recycling in Nigeria failed due to "consumption habits" as well as the political, social, economic, and cultural context, which necessitates the services of the informal recyclers. The management of WEEE in Nigeria is faced with numerous challenges, as identified by Nnorom and Odeyingbo [92], including the following:

(a) The influx of used electrical and electronic equipment approaching their end of life is frequently combined with WEEE.

(b) The rate of collection of end-of-life electrical and electronic equipment is poor, as owners usually keep them inside their cabinets and drawers, after which they are disposed of in the general waste stream.

(c) The majority of the population appears to be ignorant of the "toxicity or hazardous nature" of WEEE.

(d) WEEE is usually disposed of alongside other waste using the same bin and is taken to the open dump, thus necessitating/promoting sorting, scavenging, etc.

(e) The flow of electronic waste via recyclers in the informal sector is more than that of formal recyclers, who are fewer in number.

(f) It is difficult to source funds to establish profitable formal WEEE recycling practices.

(g) There is weak enforcement of WEEE legislation.

(h) There is "non-implementation" of the extended producer responsibility (EPR) segment of WEEE regulations.

(i) There is a lack of appropriate infrastructure for WEEE management.

(j) The primitive techniques used by the informal recyclers give rise to environmental pollution as well as energy and resource waste. 


\subsection{Challenges of Informal Recycling in Port Harcourt, Nigeria}

Goel [55] puts forward that WEEE gathering or collection in Port Harcourt is predominantly carried out by informal recyclers. They are not just involved in WEEE management alone; they gather a variety of wastes at the same time to enable them to make a living from their activities, and thus it is difficult to ascertain who is uniquely responsible for WEEE management. In [93], several informal WEEE recyclers "remain unaware of" some of the products or materials that they could recycle or recover. The same research effort explains that some of the problems of informal recycling are that it exposes human health and the environment to risk, in addition to the fact that its treatment is expensive and complex. In Vaccari et al. [94] the "spread of pollutants" from the facilities used by informal recyclers in Port Harcourt tends to affect humans via pollution transportation mechanisms "and exposure pathways".

In Yu et al. [95] informal WEEE recycling poses many challenges, yet its practice is difficult to stop due to factors such as the increasing demand for second-hand electronics and second-hand parts (for local industries), as well as the increasing need for equipment/materials (as a result of expansion of the manufacturing industries); this is the case with Port Harcourt. The recycling of lead-acid batteries by the informal sector during dismantling results in hazardous emissions. This can affect the environment as well as the health of individuals $[56,96]$.

In [97] the disposal of WEEE puts the environment and human life at great risk as a result of them being "exposed to" chemicals that are hazardous while the electronic components are being dismantled. The recyclers in the informal sector in Port Harcourt utilise crude recycling procedures as they lack the required infrastructure to ensure the safety of the environment and human life [95].

The informal recycling activities in Rumukurushi in Port Harcourt city are characterised by the following: the workers are predominantly young individuals, the working hours are about $9-12 \mathrm{~h}$ daily, and those living around the location where open burning is carried out usually experience health-related challenges, as specified in [77]. In [74] the WEEE scrappers are usually faced with the problems of bad roads, roads flooded with water after a rainfall, and the rising price of petrol, all of which affect "the availability of transport". Awasthi et al. [98] emphasised that the majority of "developing countries" are faced with the challenges associated with recycling WEEE using the informal approach, and this is because of the large population of jobless individuals who now collect and recycle WEEE at family-owned workshops.

The informal WEEE recyclers are faced with some limitations, which can be minimised with the intervention of the government and private individuals. These limitations are specified in Alabi and Wohlmuth [57] and include:

(a) A lack of essential facilities that can enhance their efforts and activities.

(b) No monetary aid nor recognition from the government.

(c) A lack of safety equipment to protect them from the health-related risks usually associated with hazardous elements.

(d) A general absence of essential training on how to protect themselves, WEEE handling, environmental issues, etc.

(e) Lack of access to adequate orientation, training, health facilities, as well as first-aid treatment in situations of emergency.

(f) Informal recyclers do not have access to proper medical services.

Omokaro [74] suggests that recycling carried out in the informal sector gives rise to several "negative environmental effects" and hence should be stopped.

\subsection{Factors That Affect the WEEE Management System in Port Harcourt, Rivers State, Nigeria}

The factors that affect the strategies adopted to manage WEEE in Port Harcourt are specified in Okorhi et al. [56] and include:

i. A lack of standardised local recycling systems. 
ii. Incorrect identification of WEEE at the entry point.

iii. Lack of awareness of the toxicity of WEEE and the difficulty in differentiating near-end-of-life EEE from WEEE.

iv. Take-back programmes are difficult to initiate and pursue, "co-loading of near E.o.L", second-hand vehicles with WEEE and EEE, and a lack of localised statistics on EEE and WEEE.

v. The inability of the government to proffer a longstanding and feasible approach to WEEE management.

vi. Users of EEE have a tendency to purchase considerably "used" ones that are close to losing their useful life as opposed to ones that are new.

Cole et al. [42] suggested that it is advisable to consider a five-point waste hierarchy for WEEE management, as shown in Figure 3.

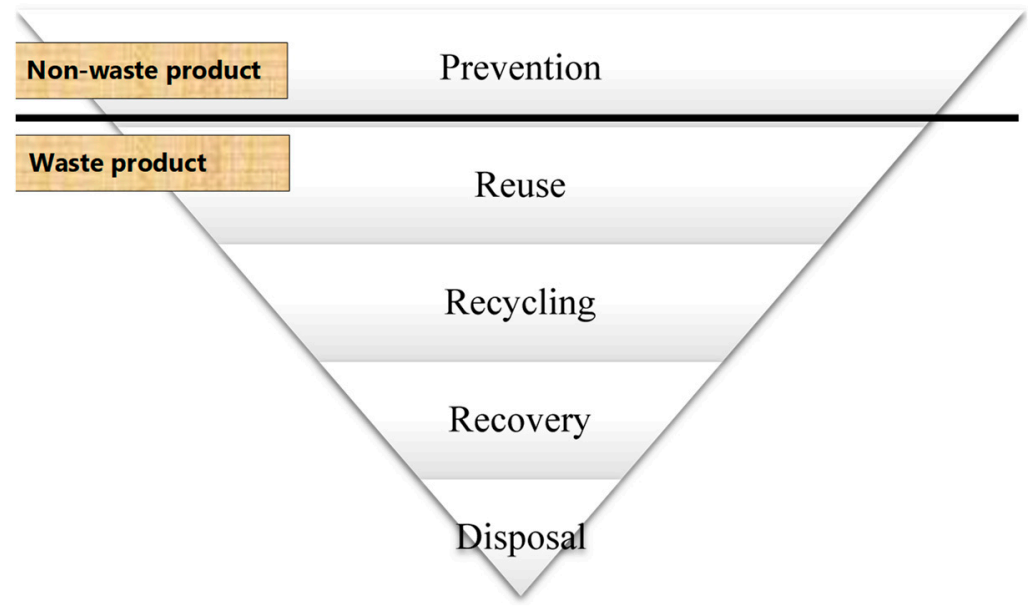

Figure 3. Hierarchy of waste.

Presently, WEEE management at MTN phone villages in Port Harcourt, Nigeria, is carried out by informal recyclers who lack basic knowledge on prevention, reuse, recycling, recovery, and disposal, as shown in Figure 3. Our study looks at approaches to change the existing WEEE management practices at the location, as its focus is to prevent the harmful and primitive style of WEEE management carried out by recyclers in the informal sector in the area and find potential applications to other regions faced with similar practices. Furthermore, if the activities of informal recyclers are drastically reduced at MTN phone villages in Port Harcourt, Nigeria the associated problems with poor recycling in the informal sector will be greatly inhibited.

\section{Materials and Methods}

This research work is geared towards "prevention", as shown in Figure 3. The research focuses on pragmatic opportunities to reduce informal recycling at MTN phone villages in Port Harcourt by reducing the involvement of informal recyclers in the management of WEEE. Two different concepts were adopted in the study, and these were:

1. Ensuring that WEEE is recovered from informal recyclers, residents, and other areas and is sent to government-approved agencies for sorting, processing, and treatment.

2. Soliciting the support of informal recyclers to engage only in WEEE collection and gathering and to be paid for these services.

A qualitative research approach [99] was adopted, as data were gathered with the help of questionnaires. The analysis of the questionnaires was achieved using graphical methods. The study participants were selected individuals from the chosen location in Port Harcourt, Nigeria. The chosen research location was a small business village, locally known as Rumukurushi's MTN phone village. The location is very small, such that the number of informal WEEE recyclers operating in the area is estimated to be about 30 persons. The 
location, even though small, is faced with the challenge of indiscriminate dumping of WEEE. This study was carried out to establish a means to limit the role of recyclers in the informal sector and the associated problems. The informal recyclers who reside in the location were consulted in order to establish a clear picture of practices in the area. The participants in the study include both males and females (i.e., 22 men and 3 women). A total of 25 participants took part in the study. Male and female participation in the survey accounted for $88 \%$ and $12 \%$, respectively. Out of the 25 informal recyclers who took part in the study, only two had attended secondary school; the remaining attended primary school only.

The study was given ethical approval after a review of the study design and documentation by the School of Computing, Engineering \& Physical Sciences Ethics Committee, University of the West of Scotland.

\section{Results and Discussion}

This study attempts to identify the main reason why the individuals in the chosen research location engage in informal WEEE recycling. The options made available to the recyclers were no job availability, zero tax payment, extra income generation, and others, as shown in Table 5.

Table 5. The reasons why informal recyclers engage in WEEE management.

\begin{tabular}{cccc}
\hline S/n & $\begin{array}{c}\text { Reasons for Individual } \\
\text { Engagement in Informal Recycling }\end{array}$ & $\begin{array}{c}\text { Number of Participants } \\
\text { in Agreement }\end{array}$ & $\begin{array}{c}\text { Participants in } \\
\text { Agreement (\%) }\end{array}$ \\
\hline 1 & Unavailability of jobs & 16 & 64 \\
\hline 2 & Zero tax payment & 1 & 4 \\
\hline 3 & Extra income generation & 3 & 12 \\
\hline 4 & Other & 5 & 20 \\
\hline
\end{tabular}

The outcomes show that the majority of the informal recyclers (64\%) admitted that the unavailability of jobs was the key reason for participating in WEEE activities. An effort was made to ascertain if the informal recyclers intend to partner with government agencies for effective WEEE management if given the opportunity. The results show that $4 \%$ of the participants strongly disagree with a partnership with government agencies, $8 \%$ disagree, $48 \%$ agree, and $40 \%$ strongly agree. The number of participants who showed positive interest in partnering with government agencies exceeds those that are not in support by a great margin. See details in Figure 4.

The readiness of the recyclers in the informal sector to accept pay for the collection or gathering of WEEE and to disengage themselves from other activities (e.g., burning, treatment, etc.) in the management of WEEE was carefully examined. According to the outcome, $4 \%$ of respondents disagree and $4 \%$ strongly disagree. Furthermore, $52 \%$ and $40 \%$ agree and strongly agree, respectively. This demonstrates the readiness of informal recyclers to restrict their activities to WEEE gathering or collection if an opportunity to be paid by the government is offered to them. See details in Figure 5.

Advantages of the WEEE Management Approach in MTN Phone Villages, Rumukurushi, a Small Settlement in Port Harcourt, Rivers State, Nigeria

The advantages associated with this approach of managing WEEE are:

- The enhancement of sustainable and safe disposal methods for materials that can cause hazards.

- The creation of room for the recovery of important elements, such as copper, gold, etc., for recycling and reuse.

- The separation of materials that can cause hazards from those that do not during WEEE dismantling is enhanced. 
- With this concept, the activities of recyclers in the informal sector are easily checked and curtailed.

- WEEE repurposing, recycling, reuse, reduction, and recovery can be achieved easily.

- It has the potential to reduce the volume of tasks carried out by informal recyclers.

- It will serve as a means of motivation for recyclers in the informal sector.

- It can offer policymakers valuable insights with regard to the management of WEEE.

- With this approach in place, it is possible to minimise the hazards presented by recycling in the informal sector.

- It creates awareness of the importance of engaging experienced and well-trained workers to manage WEEE.

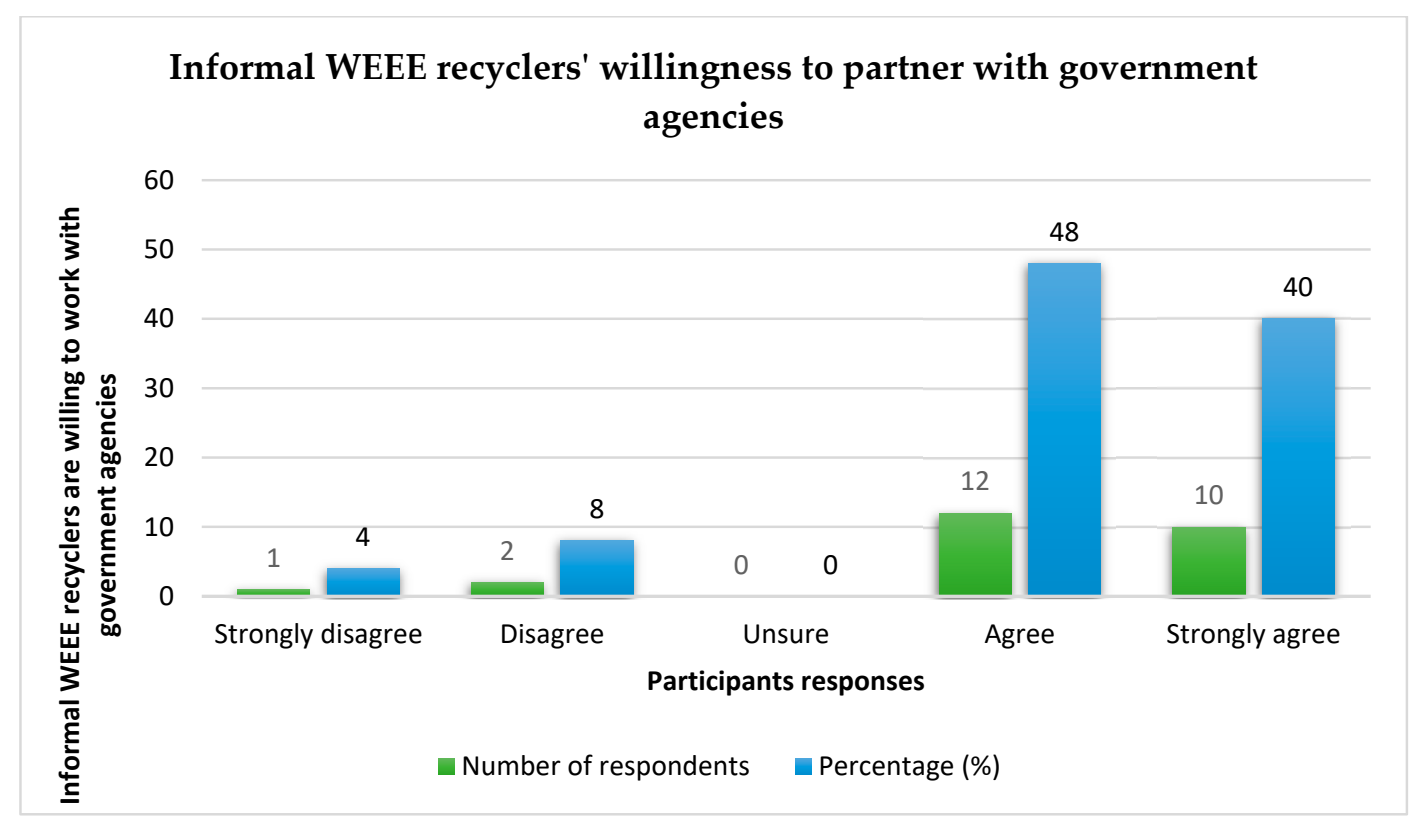

Figure 4. A plot of informal WEEE recyclers' willingness to partner with government agencies.

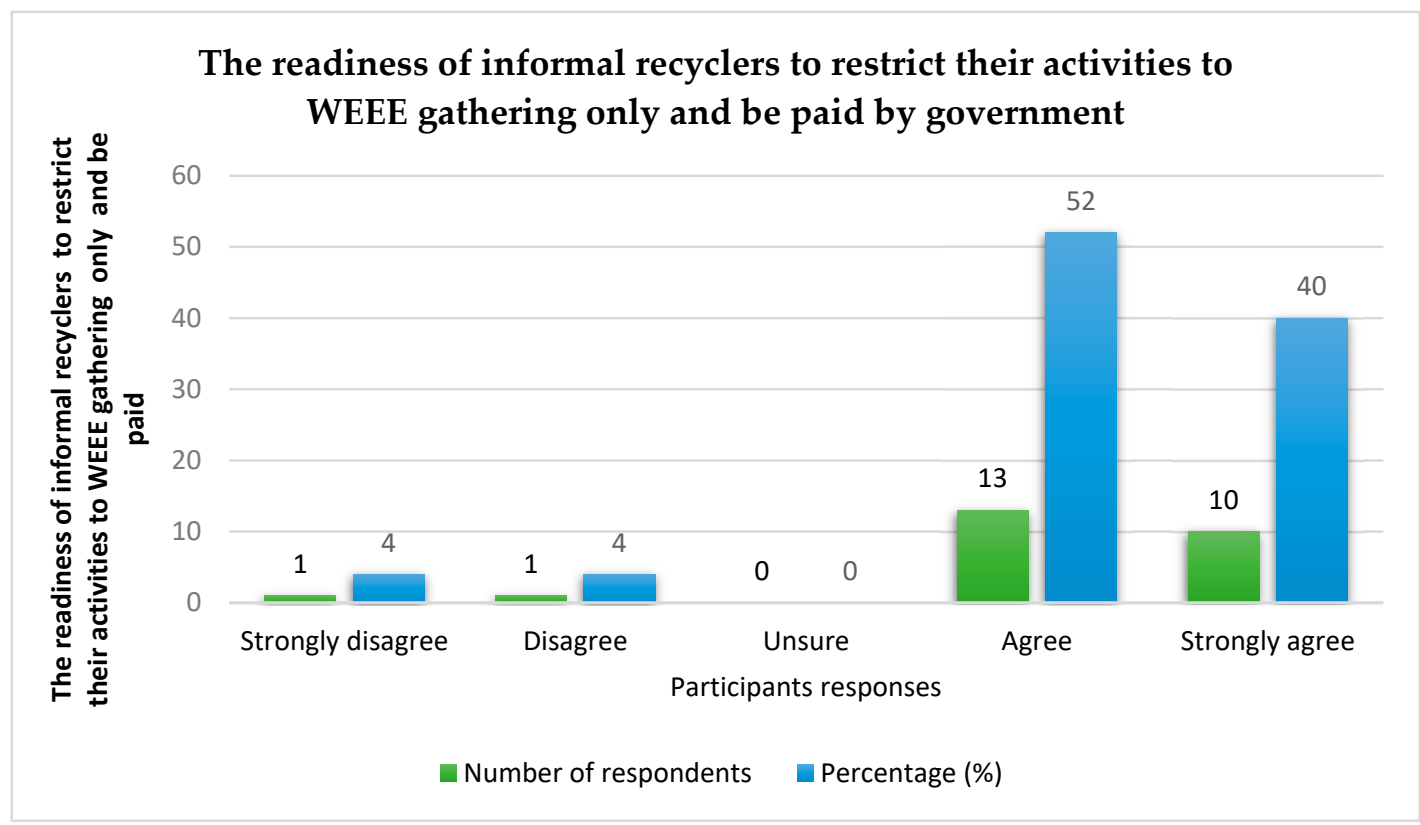

Figure 5. A plot of the readiness of informal recyclers to restrict their activities to WEEE gathering only and be paid. 


\section{Conclusions}

This study carried out a review of past publications on the management of WEEE in order to reduce risks to human health from activities in the informal recycling sector in MTN phone village located in Rumukurushi, a small settlement in Port Harcourt, Rivers State, Nigeria. A new concept of managing WEEE was introduced for Rumukurushi, which limits the activities of informal recyclers to WEEE collection only, in return for formal payment for their services. In this case, the informal recyclers do not take part in WEEE treatment, dismantling, refining, disposal, etc. Trained workers and government-approved offices are solely responsible for the management of WEEE. This provides increased productivity, efficiency, and safety. The study outcomes show that $48 \%$ agree to partner with government agencies, while $40 \%$ of those remaining strongly agree to the collaboration. The number of participants who showed a positive interest in partnering with government agencies exceeds that of those who were not in support by a great margin. In addition, $52 \%$ and $40 \%$ agree and strongly agree, respectively, to limit their activities exclusively to WEEE collection if the government is willing to pay for their services.

Author Contributions: Conceptualisation: A.H., E.V. and O.O.; methodology: E.V., A.H., L.I. and O.O.; formal analysis: E.V., A.H., L.I. and O.O.; investigation: O.O.; resources: A.H., E.V. and O.O.; data curation: E.V., A.H., L.I. and O.O.; writing-original draft preparation: O.O.; writing-review and editing: E.V., A.H., L.I. and O.O.; visualisation; A.H., E.V. and O.O.; supervision: E.V. and A.H.; project administration: E.V. and A.H.; funding acquisition, O.O. All authors have read and agreed to the published version of the manuscript.

Funding: This research received no external funding.

Institutional Review Board Statement: The study was conducted according to the guidelines of the Declaration of Helsinki, and approved by the Ethics Committee of the School of Computing, Engineering \& Physical Sciences, University of the West of Scotland (reference number 21-8607-3338, approval date: 2 November 2021).

Informed Consent Statement: Informed consent was obtained from all subjects involved in the study.

Data Availability Statement: Not applicable.

Conflicts of Interest: The authors declare no conflict of interest.

\section{Abbreviations}

WEEE: Waste electrical and electronic equipment; MTN: mobile telephone network.

\section{References}

1. Konya, R.S.; Babatunde, B.B.; Iniefe, D. Assessment of e-waste status in Port Harcourt city and its environs. Environ. Sci. 2015, 3, 45-66. [CrossRef]

2. Kalamaras, G.; Kloukinioti, M.; Antonopoulou, M.; Ntaikou, I.; Vlastos, D.; Eleftherianos, A.; Dailianis, S. The Potential Risk of Electronic Waste Disposal into Aquatic Media: The Case of Personal Computer Motherboards. Toxics 2021, 9, 166. [CrossRef]

3. Danz, P.; Aryan, V.; Möhle, E.; Nowara, N. Experimental Study on Fluorine Release from Photovoltaic Backsheet Materials Containing PVF and PVDF during Pyrolysis and Incineration in a Technical Lab-Scale Reactor at Various Temperatures. Toxics 2019, 7, 47. [CrossRef]

4. Amadi, A.I.; Chijioke, A.K. Economic and Environmental Sustainability of Informal Sector Recycling of Construction and Demolition Waste in Nigeria. AASCIT J. Environ. 2018, 3, 1-10.

5. Ohajinwa, C.M.; Van Bodegom, P.M.; Vijver, M.G.; Peijnenburg, W.J.G.M. Health Risks Awareness of Electronic Waste Workers in the Informal Sector in Nigeria. Int. J. Environ. Res. Public Health 2017, 14, 911. [CrossRef]

6. Leung, A.O.W.; Duzgoren-Aydin, N.S.; Cheung, K.C.; Wong, M.H. Heavy metals concentrations of surface dust from e-waste recycling and its human health implications in southeast China. Environ. Sci. Technol. 2008, 42, 2674-2680. [CrossRef] [PubMed]

7. Starovoytova, D. Solid Waste Management (SWM) at a University Campus (Part 1/10): Comprehensive-Review on Legal Framework and Background to Waste Management, at a Global Context. J. Environ. Earth Sci. 2018, 8, 68-116.

8. Mihai, F.C.; Gnoni, M.-G.; Meidiana, C.; Ezeah, C.; Elia, V. Waste electrical and electronic equipment (WEEE): Flows, quantities and management, a global scenario. In Electronic Waste Management and Treatment Technology; Prasad, M.N.V., Vithanage, M., Eds.; Butterworth-Heinemann: Oxford, UK, 2019; pp. 1-34. 
9. Awere, E.; Obeng, P.A.; Bonoli, A.; Obeng, P.A. E-waste recycling and public exposure to organic compounds in developing countries: A review of recycling practices and toxicity levels in Ghana. Environ. Technol. Rev. 2020, 9, 1-19. [CrossRef]

10. Bimir, M.N. Revisiting e-waste management practices in selected African countries. J. Air Waste Manag. Assoc. 2020, 70, 659-669. [CrossRef] [PubMed]

11. Bi, X.; Gareth, O.T.; Jones, K.C.; Qu, W.; Sheng, G.; Martin, F.L.; Fu, J. Exposure of electronics dismantling workers to polybrominated diphenyl ethers, polychlorinated biphenyls, and organochlorine pesticides in South China. Environ. Sci. Technol. 2007, 41, 5647-5653. [CrossRef]

12. Kitila, A.W.; Woldemikael, S.M. Woldemikael, Waste electrical and electronic equipment management in the educational institutions and governmental sector offices of Addis Ababa, Ethiopia. Waste Manag. 2019, 85, 30-41. [CrossRef] [PubMed]

13. Mihai, F.-C.; Gnoni, M.-G. E-waste Management as a Global Challenge (Introductory Chapter). E-Waste Transit. $2017,14,1-18$.

14. Zhu, M.; Shen, M.; Liang, X.; Chen, H.; Zhu, C.; Du, B.; Luo, D.; Lan, S.; Feng, Z.; Zeng, L. Identification of Environmental Liquid-Crystal Monomers: A Class of New Persistent Organic Pollutants-Fluorinated Biphenyls and Analogues-Emitted from E-Waste Dismantling. Environ. Sci. Technol. 2021, 55, 5984-5992. [CrossRef] [PubMed]

15. Needhidasan, S.; Samuel, M.; Chidambaram, R. Electronic waste-An emerging threat to the environment of urban India. J. Environ. Health Sci. Eng. 2014, 12, 36. [CrossRef]

16. Forti, V.; Baldé, C.P.; Kuehr, R.; Bel, G. The Global E-Waste Monitor 2020: Quantities, Flows, and the Circular Economy Potential; United Nations University/United Nations Institute for Training and Research and International Telecommunication Union and International Solid Waste Association: Bonn, Germany; Geneva, Switzerland; Vienna, Austria, 2020; pp. 1-120.

17. Mostafa, T.M.; Sarhan, D.S.; Tarek, M.M. Economic feasibility study of E-waste recycling facility in Egypt. Evergreen 2018, 5, 26-35. [CrossRef]

18. Ciftci, M.; Cicek, B. E-waste: A Review of CRT (Cathode Ray Tube) Recycling. Res. Rev. J. Mater. Sci. 2017, 5, 1-17. [CrossRef]

19. Lecler, M.-T.; Zimmermann, F.; Silvente, E.; Clerc, F.; Chollot, A.; Grosjean, J. Exposure to hazardous substances in Cathode Ray Tube (CRT) recycling sites in France. Waste Manag. 2015, 39, 226-235. [CrossRef]

20. Ledwaba, P.; Sosibo, N. Cathode ray tube recycling in South Africa. Recycling 2017, 2, 4. [CrossRef]

21. Xu, Q.; Yu, M.; Kendall, A.; He, W.; Li, G.; Schoenung, J.M. Environmental and economic evaluation of cathode ray tube (CRT) funnel glass waste management options in the United States. Resour. Conserv. Recycl. 2013, 78, 92-104. [CrossRef]

22. Ali, M.H.H.; Al-Qahtani, K.M. Assessment of some heavy metals in vegetables, cereals and fruits in Saudi Arabian markets. Egypt. J. Aquat. Res. 2012, 38, 31-37. [CrossRef]

23. Ismičić-Tanjo, D.; Huremović, J.; Selović, A.; Šehović, E. Human Health Risk Assessment of Mercury in Soil-Plants System. Int. J. Environ. Res. 2021, 15, 797-805. [CrossRef]

24. Natasha; Shahid, M.; Khalid, S.; Bibi, I.; Bundschuh, J.; Niazi, N.K.; Dumat, C. A critical review of mercury speciation, bioavailability, toxicity and detoxification in soil-plant environment: Ecotoxicology and health risk assessment. Sci. Total Environ. 2020, 711, 134749. [CrossRef] [PubMed]

25. Ahen, F.; Amankwah-Amoah, J. Sustainable Waste Management Innovations in Africa: New Perspectives and Research Agenda for Improving Global Health. Sustainability 2021, 13, 6646. [CrossRef]

26. Gebeyehu, H.R.; Bayissa, L.D. Levels of heavy metals in soil and vegetables and associated health risks in Mojo area, Ethiopia. PLoS ONE 2020, 15, e0227883. [CrossRef] [PubMed]

27. Zhou, H.; Yang, W.-T.; Zhou, X.; Liu, L.; Gu, J.-F.; Wang, W.-L.; Zou, J.-L.; Tian, T.; Peng, P.-Q.; Liao, B.-H. Accumulation of heavy metals in vegetable species planted in contaminated soils and the health risk assessment. Int. J. Environ. Res. Public Health 2016, 13, 289. [CrossRef]

28. Attia, Y.; Soori, P.K.; Ghaith, F. Analysis of Households' E-Waste Awareness, Disposal Behavior, and Estimation of Potential Waste Mobile Phones towards an Effective E-Waste Management System in Dubai. Toxics 2021, 9, 236. [CrossRef]

29. Clemens, S. Toxic metal accumulation, responses to exposure and mechanisms of tolerance in plants. Biochimie 2006, 88, 1707-1719. [CrossRef]

30. Nagajyoti, P.C.; Lee, K.D.; Sreekanth, T.V.M. Heavy metals, occurrence and toxicity for plants: A review. Environ. Chem. Lett. 2010, 8, 199-216. [CrossRef]

31. Omorogieva, O.M.; Tonjoh, J.A. Bioavailability of heavy metal load in soil, groundwater, and food crops manihot esculenta and carica papaya in dumpsite environment. Int. J. Environ. Sci. Technol. 2020, 17, 4853-4864. [CrossRef]

32. Sagbara, G.; Zabbey, N.; Sam, K.; Nwipie, G.N. Heavy metal concentration in soil and maize (Zea mays L.) in partially reclaimed refuse dumpsite 'borrow-pit' in Port Harcourt, Nigeria. Environ. Technol. Innov. 2020, 18, 100745. [CrossRef]

33. Marinello, S.; Gamberini, R. Multi-Criteria Decision Making Approaches Applied to Waste Electrical and Electronic Equipment (WEEE): A Comprehensive Literature Review. Toxics 2021, 9, 13. [CrossRef] [PubMed]

34. George, F.; Mapa, M.T.; Dinggai, S.A. IOP CoPreliminary Study on Waste Electrical and Electronic Equipment (WEEE) Management by Households in the Kota Kinabalu City. IOP Conf. Ser. Earth Environ. Sci. 2019, 286, 012023. [CrossRef]

35. Hossain, R.; Nekouei, R.K.; Mansuri, I.; Sahajwalla, V. Sustainable Recovery of Cu and Sn from Problematic Global Waste: Exploring Value from Waste Printed Circuit Boards. ACS Sustain. Chem. Eng. 2019, 7, 1006-1017. [CrossRef]

36. Hsu, E.; Durning, C.J.; West, A.C.; Park, A.-H.A. Enhanced extraction of copper from electronic waste via induced morphological changes using supercritical $\mathrm{CO}_{2}$. Resour. Conserv. Recycl. 2021, 168, 105296. [CrossRef] 
37. Li, Z.; Diaz, L.A.; Yang, Z.; Jin, H.; Lister, T.E.; Vahidi, E.; Zhao, F. Comparative life cycle analysis for value recovery of precious metals and rare earth elements from electronic waste. Resour. Conserv. Recycl. 2019, 149, 20-30. [CrossRef]

38. Tanısalı, E.; Özer, M.; Burat, F. Precious Metals Recovery from Waste Printed Circuit Boards by Gravity Separation and Leaching Miner. Process. Extr. Metall. Rev. 2020, 42, 24-37. [CrossRef]

39. Wang, Z.; Zhang, B.; Guan, D. Take responsibility for electronic-waste disposal. Nature 2016, 536, 23-25. [CrossRef]

40. Wang, J.; Chen, S.; Zeng, X.; Huang, J.; Liang, Q.; Shu, J.; Chen, M.; Xiao, Z.; Zhao, H.; Sun, Z. Recovery of high purity copper from waste printed circuit boards of mobile phones by slurry electrolysis with ammonia-ammonium system. Sep. Purif. Technol. 2021, 275, 119180. [CrossRef]

41. Zhang, K.; Schnoor, J.L.; Zeng, E.Y. E-Waste Recycling: Where Does It Go from Here? Environ. Sci. Technol. 2012, 46, 10861-10867. [CrossRef]

42. Cole, C.; Gnanapragasam, A.; Cooper, T.; Singh, J. An assessment of achievements of the WEEE Directive in promoting movement up the waste hierarchy: Experiences in the UK. Waste Manag. 2019, 87, 417-427. [CrossRef]

43. Ferronato, N.; Torretta, V. Waste mismanagement in developing countries: A review of global issues. Int. J. Environ. Res. Public Health 2019, 16, 1060. [CrossRef] [PubMed]

44. Khan, S.S.; Lodhi, S.A.; Akhtar, F.; Khokar, I. Challenges of waste of electric and electronic equipment (WEEE): Toward a better management in a global scenario. Manag. Environ. Qual. Int. J. 2014, 25, 166-185. [CrossRef]

45. Lawal, S. Nigeria Has Become an E-Waste Dumpsite for Europe, US and Asia. TRT WORLD. Available online: https://www. trtworld.com/magazine/nigeria-has-become-an-e-waste-dumpsite-for-europe-us-and-asia-24197 (accessed on 4 March 2020).

46. Adeola, F.O. WEEE generation and the consequences of its improper disposal. In Waste Electrical and Electronic Equipment Recycling; Woodhead Publishing: Sawston, UK, 2018; pp. 13-31.

47. Wilson, D.C.; Rodic, L.; Modak, P.; Soos, R.; Carpintero, A.; Velis, K.; Iyer, M.; Simonett, O. Global Waste Management Outlook; United Nations Environment Programme: Nairobi, Kenya, 2015; pp. 1-346.

48. Dagiliūtè, R.; Zabulionis, D.; Sujetovienè, G.; Žaltauskaitè, J. Waste of electrical and electronic equipment: Trends and awareness among youths in Lithuania. Waste Manag. Res. 2019, 37, 95-101. [CrossRef] [PubMed]

49. Tiseo, I. E-Waste Generation Globally by Key Country. 2016. Available online: https://www.statista.com/statistics/499952 / ewaste-generation-worldwide-by-major-country/ (accessed on 15 July 2020).

50. Baldé, C.; Forti, V.; Gray, V.; Kuehr, R.; Stegmann, P. The Global E-Waste Monitor 2017: Quantities, Flows and Resources; United Nations University (UNU) and International Telecommunication Union (ITU) and International Solid Waste Association (ISWA): Bonn, Germany; Geneva, Switzerland; Vienna, Austria, 2017.

51. Ogbuanya, T.C.; Afeez, Y.S. Advancing Electronic Waste Management Techniques among Electrical/Electronic Technicians' Workshops for Sustainable Healthy Society. Insights Min. Sci. Technol. 2019, 1, 90-104.

52. SArya, S.; Gupta, A.; Bhardwaj, A. Electronic Waste Management Approaches-A Pilot Study in Northern Indian States. Int. J. Waste Resour. 2018, 8, 1-5.

53. Ndunda, H.K.; Ambole, L.A. S-2018-8 Product-Service Systems Design for E-Waste Management: A Case Study of Waste Electrical and Electronic Equipment Centre in Nairobi County. In Innovation Research Symposium; School of Arts and Design, University of Nairobi: Nairobi, Kenya, 2018; pp. 73-81.

54. Aidonis, D.; Achillas, C.; Folinas, D.; Keramydas, C.; Tsolakis, N. Decision Support Model for Evaluating Alternative Waste Electrical and Electronic Equipment Management Schemes-A Case Study. Sustainability 2019, 11, 3364. [CrossRef]

55. Goel, S. From Waste to Jobs: Decent Work Challenges and Opportunities in the Management of E-Waste in Nigeria; International Labour Organization: Geneva, Switzerland, 2019; pp. 1-49.

56. Okorhi, O.J.; Joe, A.-E.; Aderemi, H.-O. New Technology Frontiers in Waste Electrical and Electronic Equipment: New Technology Frontiers in Waste Electrical and Electronic Equipment: Addressing the E-waste Management Strategies in South Eastern Nigeria. In Proceedings of the 12th Globelics International Conference on Partnerships for Innovation-Based Development, Addis Ababa, Ethiopia, 20-31 October 2014; pp. 309-338.

57. Alabi, R.A.; Wohlmuth, K. The Case of Sustainable Management of Waste in Germany (and Bremen) and Practical Lessons for Nigeria (and Lagos); University of Bremen: Bremen, Germany, 2019; pp. 1-182.

58. Okorhi, J.O.; Amadi-Echendu, J.E.; Aderemi, H.O.; Uhunmwangho, R.; Agbatah, O.B. Solving the waste electrical and electronic equipment problem: Socio-economic assessment on sustainable e-waste management in South Eastern Nigeria. Int. J. Environ. Technol. Manag. 2017, 20, 300-320. [CrossRef]

59. Borthakur, A.; Sinha, K. Generation of electronic waste in India: Current scenario, dilemmas and stakeholders. Afr. J. Environ. Sci. Technol. 2013, 7, 899-910.

60. Ilankoon, I.; Ghorbani, Y.; Chong, M.N.; Herath, G.; Moyo, T.; Petersen, J. E-waste in the international context-A review of trade flows, regulations, hazards, waste management strategies and technologies for value recovery. J. Waste Manag. 2018, 82, 258-275. [CrossRef]

61. Wideman, B.N. Grappling with the African E-Waste Pandemic: Contributing Factors and Future Deterrence. Ph.D. Thesis, Portland State University, Portland, OR, USA, 2019; pp. 1-94.

62. Auclair, B.; Ormes, G.C.; Smith, D.A.; Tourtillott, N.J. Mapping Informal E-waste Hubs from Academic and News Literature. Ph.D. Thesis, Worcester Polytechnic Institute, Worcester, MA, USA, 2020; pp. 1-111. 
63. Lu, C.; Zhang, L.; Zhong, Y.; Ren, W.; Tobias, M.; Mu, Z.; Ma, Z.; Geng, Y.; Xue, B. An overview of e-waste management in China. J. Mater. Cycles Waste Manag. 2015, 17, 1-12. [CrossRef]

64. Perkins, D.N.; Drisse, M.-N.B.; Nxele, T.; Sly, P.D. E-waste: A global hazard. Ann. Glob. Health 2014, 80, 286-295. [CrossRef] [PubMed]

65. Pérez-Belis, V.; Bovea, M.D.; Ibáñez-Forés, V. An in-depth literature review of the waste electrical and electronic equipment context: Trends and evolution. Waste Manag. Res. 2015, 33, 3-29. [CrossRef] [PubMed]

66. Khurrum, K.; Bhutta, S.; Omar, A.; Yang, X. Electronic Waste: A Growing Concern in Today's Environment. Econ. Res. Int. 2011, 2011, 474230.

67. Miner, K.J.; Rampedi, I.T.; Ifegbesan, A.P.; Machete, F. Survey on Household Awareness and Willingness to Participate in E-Waste Management in Jos, Plateau State, Nigeria. Sustainability 2020, 12, 1047. [CrossRef]

68. Wang, F.; Kuehr, R.; Ahlquist, D.; Li, J. E-Waste in China: A Country Report; United Nations University: Tokyo, Japan, 2013; pp $1-60$.

69. Gupt, Y.; Sahay, S. Review of extended producer responsibility: A case study approach. Waste Manag. Res. 2015, 33, 595-611. [CrossRef]

70. Olowu, D. Menace of e-wastes in developing countries: An agenda for legal and policy responses. Law Environ. Dev. J. 2012, 8, 59.

71. Hoeltl, A.; Brandtweiner, R.; Müller, R. Approach to solving the E-waste problem-Case study Ghana. Int. J. Sustain. Dev. Plan. 2017, 12, 1050-1060. [CrossRef]

72. Tsai, W.-T. Recycling Waste Electrical and Electronic Equipment (WEEE) and the Management of Its Toxic Substances in Taiwan-A Case Study. Toxics 2020, 8, 48. [CrossRef]

73. Osayamwen, B. E-Waste Management: A Formal Approach; Hinckley Recycling Nigeria Ltd.: Lagos, Nigeria, 2017.

74. Omokaro, B.I. Moving Forward Sustainably: Material and Social Conditions of Electronic Waste Management in Nigeria; University of Jyväskylä: Yväskylä, Finland, 2018.

75. Cruz-Sotelo, S.E.; Ojeda-Benitez, S.; Sesma, J.J.; Velazquez-Victorina, K.I.; Santillan-Soto, N.; Garcia-Cueto, O.R.; Concepcion, V.A.; Alcantara, C. E-Waste Supply Chain in Mexico: Challenges and Opportunities for Sustainable Management. Sustainability 2017, 9 , 503. [CrossRef]

76. Jain, A. Compendium of Technologies for the Recovery of Materials from WEEE E-Waste; United Nations: San Francisco, CA, USA, 2017.

77. Cesaro, A.; Belgiorno, V.; Gorrasi, G.; Viscusi, G.; Vaccari, M.; Vinti, G.; Jandric, A.; Dias, M.I.; Hursthouse, A.; Salhofer, S. A relative risk assessment of the open burning of WEEE. Environ. Sci. Pollut. Res. 2019, 26, 11042-11052. [CrossRef]

78. Okorhi, O.J.; Omotor, D.; Aderemi, H.O. Wastes from Industrialized Nations: A Socio-economic Inquiry on E-waste Management for the Recycling Sector in Nigeria. In Assessment and Management of Radioactive and Electronic Wastes; El-Din Saleh, H., Ed.; IntechOpen: London, UK, 2020.

79. Ohajinwa, C.M.; van Bodegom, P.M.; Vijver, M.G.; Olumide, A.O.; Osibanjo, O.; Peijnenburg, W.J.G.M. Peijnenburg, Prevalence and injury patterns among electronic waste workers in the informal sector in Nigeria. Inj. Prev. 2018, 24, 185-192. [CrossRef] [PubMed]

80. Bin Hameed, H.; Ali, Y.; Petrillo, A. Environmental risk assessment of E-waste in developing countries by using the modified-SIRA method. Sci. Total Environ. 2020, 733, 138525. [CrossRef] [PubMed]

81. LLuo, P.; Bao, L.-J.; Wu, F.-C.; Li, S.-M.; Zeng, E.Y. Health risk characterization for resident inhalation exposure to particle-bound halogenated flame retardants in a typical e-waste recycling zone. Environ. Sci. Technol. 2014, 48, 8815-8822. [CrossRef] [PubMed]

82. Onwughara, I.N.; Nnorom, I.C.; Kanno, O.C. Issues of Roadside Disposal Habit of Municipal Solid Waste, Environmental Impacts and Implementation of Sound Management Practices in Developing Country 'Nigeria'. Int. J. Environ. Sci. Dev. 2010, 1, 409-418.

83. Butturi, M.A.; Marinelli, S.; Gamberini, R.; Rimini, B. Ecotoxicity of Plastics from Informal Waste Electric and Electronic Treatment and Recycling. Toxics 2020, 8, 99. [CrossRef]

84. Huang, Z.; Qiu, R.; Lin, K.; Ruan, J.; Xu, Z. In Situ Recombination of Elements in Spent Lithium-Ion Batteries to Recover High-Value $\gamma$-LiAlO2and LiA15O8. Environ. Sci. Technol. 2021, 55, 7643-7653. [CrossRef]

85. Huang, Z.; Zhu, J.; Wu, X.; Qiu, R.; Xu, Z.; Ruan, J. Eddy current separation can be used in separation of non-ferrous particles from crushed waste printed circuit boards. J. Clean. Prod. 2021, 312, 127755. [CrossRef]

86. Zhu, J.; Huang, T.; Huang, Z.; Qin, B.; Tang, Y.; Ruan, J.; Xu, Z. An energy-saving and environment-friendly technology for debromination of plastic waste: Novel models of heat transfer and movement behavior of bromine. J. Hazard. Mater. 2022, 421, 126814. [CrossRef]

87. Salhofer, S. E-waste collection and treatment options: A comparison of approaches in Europe, China and Vietnam. In Handbook of Environmental Chemistry; Springer: Berlin/Heidelberg, Germany, 2018.

88. Ohajinwa, C.M. Environmental and Health Impacts of Informal Electronic Waste Recycling Issue. Ph.D. Thesis, Leiden University, Leiden, The Netherlands, 23 October 2018.

89. Gangwar, C.; Choudhari, R.; Chauhan, A.; Kumar, A.; Singh, A.; Tripathi, A. Assessment of air pollution caused by illegal e-waste burning to evaluate the human health risk. Environ. Int. 2019, 125, 191-199. [CrossRef]

90. Williams, E.; Kahhat, R.; Allenby, B.; Kavazanjian, E.; Kim, J.; Xu, M. Environmental, social, and economic implications of global reuse and recycling of personal computers. Environ. Sci. Technol. 2008, 42, 6446-6454. [CrossRef]

91. Ezeudu, O.B.; Ezeudu, T.S. Implementation of Circular Economy Principles in Industrial Solid Waste Management: Case Studies from a Developing Economy (Nigeria). Recycling 2019, 4, 42. [CrossRef] 
92. Nnorom, I.C.; Odeyingbo, O.A. Electronic waste management practices in Nigeria. In Handbook of Electronic Waste Management; Butterworth-Heinemann: Oxford, UK, 2020; pp. 323-354.

93. ILO (International Labour Organization). Tackling informality in E-Waste Management: The potential of Cooperative Enterprises; International Labour Organization: Geneva, Switzerland, 2014.

94. Vaccari, M.; Vinti, G.; Cesaro, A.; Belgiorno, V.; Salhofer, S.; Dias, M.I.; Jandric, A. WEEE treatment in developing countries: Environmental pollution and health consequences-An overview. Int. J. Environ. Res. Public Health 2019, 16, 1595. [CrossRef] [PubMed]

95. Yu, J.; Williams, E.; Ju, M.; Shao, C. Managing e-waste in China: Policies, pilot projects and alternative approaches. Resour. Conserv. Recycl. 2010, 54, 991-999. [CrossRef]

96. Zeng, X.; Huo, X.; Xu, X.; Liu, D.; Wu, W. E-waste lead exposure and children's health in China. Sci. Total Environ. 2020, 734, 139286. [CrossRef]

97. Osaretin, G.I. Toxic Metals, Cancer Risk and Genotoxicity Biomarkers in humans Exposed to Electronic Waste in Southwestern Nigeria. Ph.D. Thesis, University of Ibadan, Ibadan, Nigeria, 2018.

98. Awasthi, A.; Shivashankar, M.; Majumder, S. Plastic solid waste utilization technologies: A review. IOP Conf. Ser. Mater. Sci. Eng. 2017, 263, 022024. [CrossRef]

99. Kivunja, C.; Kuyini, A.B. Understanding and Applying Research Paradigms in Educational Contexts. Int. J. High. Educ. 2017, 6, 26-41. [CrossRef] 